\title{
Indigested in the Scenes: Hamlet's Dramatic Theory and Ours
}

\author{
Daniel L. Keegan (American U. of Sharjah)
}

(Forthcoming in PMLA, January 2018)

A signal achievement of the past half-century of theatre and performance research has been the emancipation of performance from its supposed "subordination to the primacy of the text" (Lehmann 21). ${ }^{1}$ In this process, to borrow Diana Taylor's influential terms, the repertoire of "performances, gestures, orality, movement, dance, singing" (20) and "many other forms of repeatable behaviors" (37) has been liberated from the domination of the archive, that privileged repository "of written culture defined by fixity and stability" (Worthen, Drama 65) where "documents" of authority and power are kept in a state of "house arrest" (Derrida, Archive 3). ${ }^{2}$ This liberation has taken various forms. Over the past half-century, performance studies and cognate discourses have drawn attention to a host of performances outside a text-based model (Taylor; Schechner; Lehmann; Harding and Rosenthal). At the same time, several critics have observed that even when performances are intended to be text-based players retain the capacity to hold at bay, even explode, the supposed subordination of their repertoire (Goldman;

Beckerman; Bennett; Weimann). ${ }^{3}$ More recently, in a series of important studies, W. B. Worthen

\footnotetext{
${ }^{1}$ This logocentric drama and its discontents have been discussed in relation to Greek philosophy (Weber 1-53; Bennett 13-26), the media ecology of the "Gutenberg galaxy" and its aftermaths (Lehmann 16; Lehmann; Weimann and Bruster; Worthen, Drama 1-138; Worthen, Authority 148-195), colonial projects (Taylor 16-43), and the emergence of national literatures (Bennett).

2 Taylor explains that "archive" and "repertoire" are not an absolute polarization and are "in a constant state of interaction" (21); see Worthen, Drama 64-69 and Schneider 87-110 on the "pull of a binaried relationship" between the terms (Schneider 107). For Taylor, moreover, the repertoire is not an unequivocal good and "subordination" to its "repeatable behaviors" of, for example, racism and sexism is deeply problematic.

${ }^{3}$ Michael Goldman observes the player's “ “terrific' energy” (7), and Bernard Beckerman the actor's "selfgenerative ... spontaneity" (7; Beckerman's emphasis). Benjamin Bennett claims for performers a "semiotic explosive[ness]" (180) in the face of textual subordination. Robert Weimann and his
} 
has insisted on the primacy of the repertoire not only in constituting all performances, both textbased and not, but also, through the repertoires of scribes, editors, printers, and others, in constituting the dramatic text—and the archive-itself. ${ }^{4}$ As Worthen shows, it is the repertoire's "technologies of performance" that "instrumental[ize]" (Drama xvi) and put to "work" (34)_ that have always instrumentalized and put to work, even in times of the text's supposed primacy - the "tool" of dramatic writing (24). ${ }^{5}$

If performance has recently been emancipated from the text, a homologous impulse has for centuries, if not millennia, sought to liberate a "literary" dimension of dramatic writing from involvement in the practices and pleasures of performance. ${ }^{6}$ With a history traceable to Aristotle's claim that Tragedy "reveals its power by mere reading," this impulse has had a special traction in relation to Shakespeare. Indeed, this impulse to liberate literature from performance is, in English drama, contemporaneous with Shakespeare. A "literary” English drama, with lines able to be "extracted from their dramatic situation and the character who articulates them" (Lesser and Stallybrass 415), emerged in the course of his career through the work of readers, authors, and printers who in various ways highlighted such "extract[able]" maxims, sentences, and commonplaces. Further, the sheer length of certain plays by Shakespeare might, as Lukas Erne argues, provide a window into the playwright's emerging literary ambitions and his "care[] for a readership for his playbooks" (17). In the past two hundred years, the ethical thrust of this liberation of Shakespeare's "literariness" has intensified. Charles Lamb

collaborators have studied the highly flexible interplay between "actor's voice" and "author's pen" on the English Renaissance stage.

${ }^{4}$ See also Rebecca Schneider's framing of "the archive as another kind of performance" (108; Schneider's emphasis).

${ }^{5}$ Worthen's Drama and Shakespeare and the Authority of Performance treat these questions most directly.

${ }^{6}$ Worthen discusses and critiques the recent resurgence of claims for Shakespeare as a "literary dramatist" (Lukas Erne's phrase) in Shakespeare Performance Studies 30-79. 
wrote in 1811 that to try and manifest Shakespeare's poetic richness on the stage, amidst the theatre's "juvenile pleasure[s]," is to go "in quest of an unattainable substance." More recently, Harry Berger, Jr. has written that drama — and writing in general—is "overwritten from the standpoint of performance and the playgoer's limited perceptual capacities” (Imaginary 29-30), an evaluation that is part of his "intrepid defense of the primacy of page over stage" (de Grazia 545). The "overwrittenness" Berger diagnoses demands to be extracted from the theatre and subjected to "decelerated reading" (Imaginary 45), a practice that affords paging back and forth, lingering over evidence at one's own pace. ${ }^{7}$ For all their variety, these versions of dramatic "literariness" all partake of the intuition that drama is "overwritten from the standpoint of performance," whether from the standpoint of the "dramatic situation" (the readers, authors, and printers discussed by Lesser and Stallybrass), the "two-hours' traffic of [the] stage" (Erne; Romeo and Juliet Prologue. $12^{8}$ ), the "juvenile pleasure" of theatre (Lamb), or the "playgoer's perceptual capacities" (Berger).

These two narratives - performance's emancipation from the text and literature's emancipation from performance- - have dominated conversations about the relationship between writing and performance. In what follows, I would like to tell an alternative story about this relationship, one that emerges in the course of Shakespeare's Hamlet. This story does not find "literature" escaping or being extracted from the theatre. Instead, it finds "literature," as

\footnotetext{
${ }^{7}$ For an assertion of the ethics of the page, see Berger, Situated 99-128. Berger's modeling of performance as a form of reading has been criticized on behalf of performance by Garner 48-49; Worthen, Authority 175-77; and Ridout 72-77.

${ }^{8}$ With exceptions, Shakespeare citations are from Greenblatt, et al.. Hamlet citations are from Thompson and Taylor's 2006 Arden edition's Second Quarto (Q2) text; notes from Jenkins' 1982 Arden edition are indicated by the editor's name.
} 
"overwrittenness," "9 being crammed into the scene of performance. This digestion, to employ the play's jargon (2.2.377), of "overwrittenness" is not a smooth thing. Rather, it is an indigestion, one that afflicts all participants in the event of dramatic performance. This indigestion challenges the playgoer's capacity to attend to the play's "necessary question[s]" (3.2.40). It disrupts the performer's ability to "speak the speech ... trippingly on the tongue" (3.2.1-2) and to "give it"dramatic performance—-"smoothness" (3.2.8). It disables every theatrical participant's ability to control and to put to work, in Worthen's sense, writing as it goes on a "progress through the guts" of the theatre (4.3.29-30). This indigestion, for all that it afflicts performance with writing, does not reinstitute the subordination of performance to the text. Instead, it highlights the fraught, uncertain interplay between writing and performance, not by insisting on the performer's capacity to hold at bay, even explode, the supposed subordination of their repertoire (Goldman;

Beckerman; Bennett; Weimann) but rather by pointing out and elaborating the indigestive "overwrittenness" of writing and its effects on the repertoires of the theatre's inhabitants. ${ }^{10}$

By (in)digesting writing — and, more, writing's overwritten literariness - into performance, Hamlet tells us a more rambunctious story about writing's participation in performance and enriches our understanding and experience of writing's involvement there. But the payoff of this investigation is not only theatrical and aesthetic: it is also political. In the play,

\footnotetext{
9 This is not to define "literature" as "overwrittenness" but to observe that drama's "literary" dimension has habitually been so defined in relation to performance, especially for Shakespeare. For an alternative perspective on "Shakespeare as literary dramatist" see van Es 56-75.

${ }^{10}$ Important suggestions have been made in this direction. Worthen regularly notes the "conceptual . . . leverage" that the repertoire gains from "the friction of writing" (Drama 83; see also Weimann, "Performance" 25; Worthen, Shakespeare Performance Studies 19). Schneider's "chiasmic tangle of bodies with language and language with bodies" (67) suspends an organizing principle; Phelan's "oversounds" disrupt protocols of interpretation ("Just Want To Say"). Hamlet's indigestive dramaturgy, I'd argue, affords a thorough-going investigation of these suggestions and the not only frictive but disabling potentialities of writing in the repertoire.
} 
the (in)digestion of overwrittenness is staged as a redesign of drama's theatrical participation, a redesign that demotes it from something like an authoritative, "archival" position. This redesign democratizes the theatrical scene precisely by debilitating the behaviors of playgoer, player, and indeed all theatrical participants and, thus, insisting on the many repertoires with claims on any given theatrical moment. In its democratizing thrust, then, Hamlet's indigestive dramaturgy ${ }^{11}$, as I would call it, dovetails neatly with the democratizing impulses that animated many of the “emancipations" and "liberations" of performance from writing and writing from performance, whether these sought to broaden the coalition of performances beyond a text-based minority (performance studies) ${ }^{12}$; to insist on the freedom of the actor with respect to the text (Goldman, et al.) and on Benjamin Bennett's titular claim that "All Theatre is Revolutionary Theatre"; or to rescue writing from performance and for the study where it can be perused, interpreted, and deliberated upon in ways that challenge the "coercively timebound sequence of performance" (Berger, "Text against Performance" 51). In all of these cases, however, it is precisely writing in performance that represents the un- or anti-democratic scenario. In Hamlet, by contrast, the (in)digestion of writing in performance democratizes the theatrical scene. As we turn to the text, we might put the matter thus: if, for Worthen, dramatic performance is in technical, economic terms as the putting to work of the tools of writing - he also calls these tools, as I will, "agencies" of writing (Drama 24)—Hamlet asks what happens if we take our metaphors for dramatic performance out of the office, out of the factory, and to the party, the protest, and the debate.

\section{The Well Digested Blurb}

\footnotetext{
${ }^{11}$ I use "dramaturgy" to indicate the whole process of dramatic performance from composition through performance to reception.

${ }^{12}$ See, recently, Sack who emphasizes the radical potentialities unleashed by unscripted performance.
} 
I heard thee speak me a speech once-but it was never acted, or, if it was, not above once, for the play I remember pleased not the million, 'twas caviare to the general. But it was, as I received it, and others whose judgements in such matters cried in the top of mine, an excellent play, well digested in the scenes, set down with as much modesty as cunning. I remember one said there were no sallets in the lines to make the matter savoury nor no matter in the phrase that might indict the author of affection but called it an honest method. (Hamlet, 2.2.372-381)

Let us begin by examining the metaphor that organizes the play's modeling of writing's — literature's — participation in performance: digestion. Doing so will situate our discussion in relation to some of the play's well-known reflections on theatre, including on the role of the clown; on Hamlet's show-passing within; and on the connection (or disconnection) between Hamlet's enunciations of performance theory and his and his play's performance practice. In relation these widely studied issues ${ }^{13}$, my own claim can be simply stated: we ought to pay more attention to the specificity and independence of Hamlet's first and less famous ${ }^{14}$ statement on dramatic theory.

I call this earlier statement Hamlet's "Blurb" for its resemblance to the promotional copy on book jackets and to distinguish it from his later, more famous Advice to the Players. For Hamlet, as for most commentators, his two statements point together towards a common goal: a judiciously composed and enacted scene that "hold $[\mathrm{s}]$. . . the mirror up to Nature" (3.2.21-22) and that, in doing so, will be well received by the judicious and the sophisticated. These two

\footnotetext{
${ }^{13}$ On this voluminous criticism, see especially Worthen, Drama 94-111; and Weimann, "Mimesis."

${ }^{14}$ Its lack of renown is attested by the fact that Hamlet's celebration of the "excellent play," in contrast to the Advice to the Players (3.2.1-43), has until now lacked a name.
} 
statements, however, sport crucial differences which have gone unremarked. ${ }^{15}$ Unlike the Advice, which concerns the behavior of actors, this Blurb concerns the ethics of dramatic composition. As a consequence, their diagnoses of failure diverge. ${ }^{16}$ For the Advice, failure is sited in an overwrought repertoire that risks abandoning word, Nature, and humanity (3.2.1-34). For the Blurb, failure is in the script. While the Advice provides vivid descriptions of an overwrought repertoire, the Blurb is more circumspect in its account of writing's failures. I seek to unpack this account here.

It is also in this Blurb, quoted in full above, that the digestive metaphor for dramaturgy is articulated. Hamlet describes an untitled "excellent play" as "well digested in the scenes." Such "scenic digestion" evidently refers to the work of "the author" in "set[ting] down" the "lines" and "phrase[s]" of the script. The author has skillfully "[d]isposed in or reduced to order" ("digested" $O E D$ 1, from 1588) the matter of the script, both in its form and its content. An indigested script, we can assume, would be one that was not so disposed in or reduced to order. According to Hamlet —or, rather, according to "one" Hamlet "remember[s]" - this indigested script would be afflicted by "sallets in the lines to make the matter savoury" and "matter in the phrase that might indict the author of affection." According to Ann Thompson and Neil Taylor, the most recent Arden editors, "sallets" is "usually glossed as "spicy bits"”_ "ribaldries," according to their predecessor Harold Jenkins (Jenkins 2.2.437n)—but may indicate nothing more than "a variety of ingredients in the dialogue to make it well seasoned" (2.2.379-80n). Using their glosses, we can paraphrase the second prohibition against "matter in the phrase" as "nothing in the manner of expression that might accuse the author of affectation" $(2.2 .380 \mathrm{n}$,

\footnotetext{
${ }^{15}$ Weimann, the most dedicated commentator on this question, assimilates these two statements ("Mimesis" 282).

${ }^{16}$ On "failure" in theatre and performance see Ridout; Bailes; O'Gorman and Werry. Hamlet emphasizes the role of dramatic agency in such failure.
} 
$381 \mathrm{n})$, affectations that might include "[t]hree-piled hyperboles" and "[f]igures pedantical" (Love's Labour's Lost 5.2.407-8; qtd. 2.2.381n).

An indigested script, on this account, would be afflicted with a species of overwrittenness, crammed with "ribaldries" and "a variety of ingredients" including hyperbolic and pedantical figures. I want to argue that, for the Blurb, such a script is also afflicted with something like one of the types of overwrittenness we are interested in here: Berger's theatredefying, literary overwrittenness. At first glance, these two types of overwrittenness might seem to contrast: the sallet-ridden script is overwritten from the perspective of theatrical judiciousness, not "perceptual capacity." Moreover, there is the suggestion that these "sallets" and this "matter in the phrase" would be designed to "please[] . . the million," not to entice Berger's "decelerated reader." And yet, what if the sallet's "variety of ingredients" not only served to "make the matter savoury" and to accuse authorial judiciousness but also posed a challenge to the perceptual capacities of the playgoers? What if "sallets" distracted these playgoers from the "necessary question[s] . . . then to be considered," confronting them with a variety of stimuli"ingredients"- that forced them to negotiate, on the fly, between the relative necessity of various questions or, perhaps, to choose between the rigor of necessary questions and the savoriness of the sallets? This interpretation suggests a connection between the dramatic "sallet" and Hamlet's mighty opposite in authorship: the clown, who according to the Advice diverts the audience with his inopportune laughter and, perhaps, some sallets—in the sense of "spicy bits," "ribaldries"of his own. ${ }^{17}$ Some link between indigestion and Hamlet's fantasy of theatrical clowns-who

\footnotetext{
17 This connection between clown and writing arguably provides a more accurate picture of the clown's theatrical role than does Hamlet's Advice. The clown was less the anti-author that Hamlet and many critics depict him as and, as Richard Preiss shows, more of an additional and often allied pole of authority in the "authorial competition[s]" (7) of the playhouse with its "elemental clash between performer and spectator" (15).
} 
"will themselves laugh to set on some quantity of barren spectators to laugh too" (3.2.38-39)—is historically plausible. Robert Weimann remarks that laughter, the clown's stock-in-trade, was understood to have a "strong visceral component" (Author's 175) ${ }^{18}$ which was part of its challenge to the "new cult of decorum" (Keith Thomas, qtd. Weimann, Author's 175) that Hamlet advocates even as he fails to embody it. ${ }^{19}$

Identifying the sallet with the clown does not, however, obviously imbue it with the sort of perceptual challenges that Berger diagnoses. Instead, it seems to do the opposite. For Berger, in what we might call his "paradox of dramatic poetry," the rich, overwritten signification of dramatic writing means that this richness must somehow fail in the theatre (or that the theatre must fail this richness). The clown, by contrast, is one of the early modern theatre's key figures, and if the written sallet is, indeed, to be associated with the clown, then it might well possess, like the clown, a certain "villainous" even "pitiful ambition" $(3.2 .41,42)$ towards distracting from the "necessary question[s]" under consideration, foisting upon playgoers a choice between its antics and the necessary questions. Berger's overwrittenness demurs at performance; the clown seeks to conquer it.

And yet, the savoury sallet, even if it clowns, might precisely demur at performance through its destined digestion. The metaphors of "caviare" and "savouriness" activate the gastronomical sense of "sallet" and, if it is digested in this sense, the sallet would be conducted into the play's paradigmatic zone of perceptual challenge: "that within" to which Hamlet lays claim and which, in his account, "passes show" (1.2.85). By plunging the clown into Hamlet's

\footnotetext{
${ }^{18}$ Clowns were generally "aligned with the lower bodily stratum," as in John Marston's Histriomastix, Or The Player Whipped in which "the "common' actors" engaged in clowning are given "names such as "Gutt," "Belch," and "Gulch" (Hillman 46).

${ }^{19}$ On the fraught relationship between Hamlet's prescriptions and his performances see Weimann, “Mimesis"; Weimann, Author's Pen, 18-28 and 151-79.
} 
"within," the sallet would enact an inscrutable populism and doubly challenge playgoer perception: insofar as it is linked to the clown, it aspires to challenge playgoer perception through distracting antics; insofar as it is digested, it slips into a show-passing, interior space.

The sallet, on this account, splices together two of the play's most famous and most opposed theatrical figures: the show-interrupting clown and the show-passing "within." The Blurb, I would argue, stages precisely this genetic recombination of clown and "within," and it does so through its own infiltration by overwrittenness. In the second of the Blurb's prohibitions, Hamlet recounts the outlawing of "matter in the phrase to indict the author of affection." We have glossed this as a prohibition against "affectation" and affected language (cf. 2.2.381n), but in this moment Hamlet indulges in — or stumbles into - a punning connection between "matter" and "mater," the Latin for "mother." Hamlet thus warns playwrights against not only "of affectation" but also "of affection" manifested through "mother in the phrase." The mother/mater pun will be explicitly activated in Act Three when Hamlet declares, "but to the matter-my mother" (3.2.316), but its presence here is confirmed by the "sallet." We have seen this term name overwrittenness, but it is itself overwritten. The first definition of the term given in the OED is not the possibly "spicy" "variety of ingredients" suggested above but, in reference to "medieval armor, a light globular headpiece" (OED 1a); in the hands of Thomas Heywood, the term was made to refer "jocularly ... to a measure for wine" (OED 1b; 1599, original emphasis). Hamlet's prohibition against "sallets" is haunted by a prohibition against the poison/wine-filled helmet of his father. Through overwrittenness, the "sallet" and "matter" coalesce into a furtive version of Hamlet's family tree.

Like the clown, these overwritten terms challenge perception by taking leave of the necessary questions then to be considered: Hamlet's attempt to put them to work in blurbing an 
“excellent play." Unlike the clown, they do so quietly, not through gregarious laughter but through a Latin pun and a joke about armor. They don't stop the show, they sulk on its margins. And yet, the show-passing sulk of "matter" and "sallet" is belied by their invocation of the even more necessary questions of the play: Hamlet's poisoned father, his affection for his mother, his filched inheritance. These sallets challenge the repertoires of the theatrical scene's inhabitants. They challenge the playgoer, as well as Hamlet's interlocutors, to perceive them and to interpret their relationship to the current scene. They doubly vex Hamlet's behaviors: his repertoire of criticism and speech is deflected into this tacit family tree and even if he has punning overwrittenness in mind, his repertoire of revenge is indicted by this reminder of the questions to which he ought to be, in this moment, attending.

The obscure clowning of these sallets reverberates through the repertoires of those not present for the performance. It is not only the repertoires of Hamlet and his audiences that are vexed but also the play's original critic's: the critiques of "sallets" and "matter in the phrase" are, after all, things Hamlet "remember[s] one said." These terms have had their punning overwrittenness emerge (or, certainly, intensify) since their original enunciation, predating Hamlet's father's death as it does. Since his mother's remarriage, Hamlet has had more serious mater issues; since his encounter with the Ghost, he has more reasons to worry about a wine/poison-filled "sallet." The Blurb thus engages overwrittenness not only with respect to theatrical judiciousness, playgoer perception, and player's enunciation, but also with respect to "dramatic situation": like the "funeral baked meats" that, as Hamlet complains, "[d]id coldly furnish forth the marriage tables" for Claudius and Gertrude (1.2.179-80), the Blurb is "furnished 
forth" in a scenario that no longer suits. ${ }^{20}$ Its "leftover" ${ }^{21}$ language is extracted from its "dramatic situation" and digested into one where the words no longer suit the actions - the work — that Hamlet and the original reviewer propose to accomplish with them.

Does this multidimensional overwrittenness enforce an escape from the theatre? Are we obliged to smuggle these sallets out of the theatre and furnish them forth into the study? There is, of course, no shame in doing so, especially for a modern audience with small Latin and less knowledge of medieval armory, and the reading that I have presented here is completely the product of "decelerated reading" practiced outside the flux of the theatre. What, then, about an early modern audience? I think this is the wrong question. We don't need to guesstimate the aural bandwidth of an Elizabethan or to identify the segment of the audience that might have the educational attainment to follow these sallets or the disposable income to watch the play repeatedly and work out the jokes. Instead, we can observe that the Blurb's sallets simultaneously insist on a theatrical habitation — through, especially, their affiliation with the clown and the play's most necessary questions — while intimating an escape from it. At the very moment that they distract from and disjoin the necessary, "timebound" questions of the scene, they are thereby affiliated with the paradigmatically theatrical clown who, much to the dismay of both, is crammed into the show-passing guts of the prince, from where these sallets point towards the play's even more necessary questions which, for the moment, seem to have been forgotten.

\footnotetext{
${ }^{20}$ On the play's queasy relations to food and, especially, meat, see Borlik.

${ }^{21}$ The furnishing forth of the Blurb recalls what Stephen Greenblatt has termed "the problem of the leftover" (Gallagher and Greenblatt 141) - the early modern anxiety provoked by the "recalcitrant, ineradicable" "material remainder" of the sign $(144,141)$, especially in Reformation Eucharistic theology. The disruptive vigor of these leftovers contrasts with Worthen's analysis of "Doing Things with (Old) Words" which emphasizes the choices made by the repertoire in the digestion of "old words" (Drama 112-123).
} 
Writing, for the Blurb, cannot easily be contained by the theatre, but it also cannot quite escape from it. Its tangled topology emerges through the indigestion of the behaviors of the participants: neither clown nor critic, prince nor playgoer is able to well digest the duplicitous (or, rather, multiplicitous) agencies of writing. Such repertorial indigestion is, beyond the Blurb, one of the dramas of Hamlet itself. Overwrittenness, as we shall see in the next section, deposes the claims to rhetorical (and, more broadly, aural) authority and efficacy that characterize the play's first act. By the end of the play, overwrittenness and the indigestions to which it gives rise will have progressed through the socio-political sphere not only of Denmark but also of the play's whole history from its earliest sources to he who played it yesterday (or, as we shall see, in 1636). This indigestive progress opens a democratic space of collective response. If no one can well digest the scene, why shouldn't everyone get a try? Why might not the reading of the Blurb presented here have come to pass not (or not just) through laborious, decelerated reading but among a group of friends at an after-party, one of whom happened to have been apprenticed to an armourer, one of whom really enjoyed Latin jokes, and the last of whom happened to have a few extra coins to see the show more than once?

\section{From "Globe" to "Machine"}

Hamlet's indigestive dramaturgy unfolds a redesign and democratization of writing's participation in performance. This redesign deposes an authoritarian model of rhetorical efficacy that evokes the textual "primacy" from which performance has been, in the last half-century, liberated. In Hamlet, however, this liberation is not complete. Instead, individual repertoires are afflicted by the agencies of writing; this affliction does not, however, subordinate the repertoire but opens up a democratic space of collective engagement. Attending to this indigestive affliction qualifies recent efforts to highlight Hamlet's emancipation of performance from 
writing (Worthen, Drama 94-111; Trudell). Instead, it brings an important topic of Hamlet criticism — the play's habit of "materializing the word" (Ferguson 271) and letting it "act upon the body" (Pollard 135) — in contact with its modeling of dramaturgy and the repertoire. ${ }^{22}$

This indigestive redesign is inaugurated over the tract between two of the play's most famous dramatic agencies: Hamlet's "globe" and his "machine." Along the way, it enacts the downfall of a cosmic, theatrical, and political paradigm. Let us begin with the "globe." Hamlet's - and Hamlet's - "globe" is famously overwritten, but it is overwritten in a way that does not challenge playgoer perception or scenic digestion. Indeed, it seeks to promote such digestion. To set the scene, recall that the "globe" is enunciated immediately after Hamlet's interview with his father's ghost and as part of a promise to remember: "Remember thee?" Hamlet exclaims, "Ay, thou poor ghost, whiles memory holds a seat / In this distracted globe" (1.5.95-97). The "globe," however, is not content with the simple assignment of referring to Hamlet's head; it ripples concentrically outward to implicate the seat-holding inhabitants of the Globe Theatre and even of the "great globe itself" (Tempest 4.1.153) beyond the theatre. This concentric effect aims to reinforce, not disable, Hamlet's promise in two ways. First, it seeks to yoke the inhabitants of the Globe and the "great globe" as collaborators in Hamlet's promise: if he is ever at risk of forgetting his father, he can always ask the audience! Second, it situates Hamlet's remembering globe in the sort of "privileged topology" that, for Derrida, characterizes the archive (3). Archivization is Hamlet's task in the ensuing lines: he claims the "book and volume of his brain" as the topology where his father's "commandment all alone shall live ... Unmixed with baser matter" (1.5.103, 102-104). The "globe" and its concentric rings radically

\footnotetext{
${ }^{22}$ On this materialized language, see also Sale. Ferguson emphasizes the materialization of overwritten text; Sale and Pollard link materialization to digestion, more in the context of reception than the repertoire.
} 
privilege this topology in turn by evoking a geocentric cosmos and the stability of its crystalline spheres. Hamlet's "globe" would in this scenario be cast in a cosmically central, proverbially immobile position, a position "defined," like the archive, "by fixity and stability" (Worthen, Drama 65).

The "globe," and its overwrittenness, participates in an effort to digest Hamlet's behaviors, subordinating his repertoire to his promise and his father's commandment; it also seeks to digest — dispose in or reduce to order — his audience's attention. By implicating the audience — and all humanity — in his promise, Hamlet aims to dispose and order them according to the necessary questions of remembrance and promise that, for him, are presently under consideration. This overwritten effort to digest the audience aligns with a broader model of reception characteristic of the play's first act, one that finds sound seizing on and subordinating the repertoire of its auditors in a way that, as Allison K. Deutermann writes, was at the turn of the seventeenth century "becoming associated with certain kinds of plays - revenge tragedies, heroic romances, and other older but still popular forms" (233). To whit: a rooster seizes the repertoire of the Ghost, obliging him to "fade[] on the crowing of the cock" (1.1.156). The Ghost's commandment obliges Hamlet to a revenge "as swift / As meditation or the thoughts of love" (1.5.29-30) and, later, to remembrance (91). The "poisonous audition" (Pollard 123-43) of Claudius" "hebona in a vial" (62), poured in the "porches" (63) of Old Hamlet's ears, seizes immediately "all [Old Hamlet's] smooth body" (73). Claudius' political technologies, from assassination on, feature such compelling sounds, whether in administering poison in Old Hamlet's ear or in insisting that the "King's rouse" be accompanied by a burst of "cannon to the clouds" $(1.2 .127,126)$. The King's politics — including his domineering appeal to those "better 
wisdoms" who "have freely gone with this affair along" (1.2.15-16) — might, to Hamlet's dismay, serve as a sort of motto for the rhetorical and aural strategy of the "globe."

Through its overwrittenness, the "globe" and its concentric spheres serve as a diagram for this model of well digested theatrical reception, mapping its vintage_—“older but still popular”theatrical sound onto a legacy cosmic system. Like Hamlet's dramatic theory, the "globe" imagines a well-suited relationship between "action" and "word"; unlike Hamlet's theory, this relationship is less characterized by judicious writing and acting and more by authoritarian, repertoire-seizing speeches and sounds. With the advent of the "machine," things change. Action is emancipated from its subordination to the word, and the word becomes unsuitable to the actions undertaken with it. This unsuiting of the word- "machine" — to its actions arises through the intervention of writing and, with it, language's capacity to be furnished forth and redigested — or indigested — in new scenarios.

Let us consider the contrasting overwrittenness of the "machine." Like the "globe," the "machine" functions in Hamlet's repertoire of promising, engaging his body or part of it in what seems the characteristic form for his protestations of faith and constancy. Unlike the "globe," the "machine" appears in writing. In a letter to Ophelia which has encouraged her to "Doubt that the stars are fire / Doubt that the sun doth move / Doubt truth to be a liar / But never doubt I love," he concludes with the declaration that he is "Thine evermore, most dear lady, whilst this machine is to him" (2.2.114-17, 120-21; emphasis added). By the time of the letter's appearance in the play, however, Hamlet's machine-his body_has taken leave of the qualities that would allow it to support the action of his promise. This promise was predicated on his possession of his body, but his body now seems possessed and ready to go to pieces, emitting sighs "so piteous and profound / As [they] did seem to shatter all his bulk / And end his being" (2.1.91-92). These 
sighs and his "afright[ing]" (72) appearance are, in turn, precisely why the letter is furnished forth at this moment and put to work in Polonius' repertoire of investigation, providing the key evidence of Hamlet's love "lunacy" to Claudius and Gertrude. Just as it exceeded Hamlet's “dramatic situation" and amorous promise, Hamlet's body-machine resists Polonius' actions. The shivering repertoire of which Polonius is aware points for playgoers beyond the encounter with Ophelia to recall that this body has been shivering in the "shrewd[ly]" "bit[ing]" wind (1.4.1) and has been encountering ghosts that "shake our disposition / With thoughts beyond the reaches of our souls" (1.4.55-56).

Hamlet's body-machine takes leave of the actions that Hamlet and Polonius seek to perform with the letter. The "machine," as a piece of writing, similarly unsuits itself to these proposed actions. Once perhaps a wholesome, well digested word, "machine" has been afflicted with leftovers and converted to an indigestible sallet by the events of the play. It possesses the following recalcitrant meanings: "A material or immaterial structure, esp. the fabric of the world or of the universe; a construction or edifice" (1a, attested from 1545; emphasis added); "A scheme or plot" (1b, from 1595-6); and a "military engine or siege-tower" (2a, from 1583). Except for the cosmic-machine, which chimes with Hamlet's rhyme about the sun and the stars, these senses are not "well digested" by the questions of the play to be resolved either through Hamlet's promise to Ophelia or Polonius' inquiry into Hamlet's love madness. Instead, these leftover senses are activated and gobbled up by the even more necessary questions of the play. The cosmic-machine (1a), besides its tinny play in the letter, recalls the dialect and stakes of the meetings with the Ghost when eyes might "start from their spheres" (1.5.17) and "heaven and earth" are crammed with "more things ... than are dreamt of in ... philosophy" (165, 165-166). The scheme-machine (1b) recalls the plots that were revealed and hatched on that same platform, 
and the siege-machine (2a) evokes the armored Ghost who so recently besieged the battlements and the watch.

Hamlet's "globe," for all that it was "distracted," optimistically envisioned consonance between the questions of the play and the attention of the audience. The "machine," by contrast, is entirely distracting. Like the "sallet" and "matter" of the Blurb, it challenges the perceptual capacity of the playgoer to negotiate between the questions then to be considered and the more necessary questions it raises. It also highlights the somatic dimension of the (in)digestive metaphor by staging the digestion of its leftover agencies into Hamlet's show-passing "within." We can begin to track this staging by noting a sense of "machine" not recorded in the OED: in Tottel's Miscelleny (1557) we hear of "[t]he machine huge Troyans suspected not" (227; emphasis added) and in George Turberville's Epitaphes, Epigrams, Songs, and Sonets (1567) he writes of "the Machin huge ... [b]y Grecian guile so falsely wrought" (106 [241]23; emphasis added). Hamlet's "machine" is linked to the paradigmatic siege-machine, one fashioned as a hollow, secretive animal body that could at any moment open and unleash either warriors or groans. This latter potentiality is introduced in the 1592 translation of Francesco Colonna's Hypnerotomachia Poliphili whose narrator, having descended into a hollow brass "Colose" in the form of a human body, cries for love so that "the whole Colose and Machine of brasse did resound, striking me into a horrible fear" (14; emphasis added); he was concerned, perhaps, that these resonances would "shatter all his bulk / And end his being."

We can track the infiltration of overwrittenness into this machinic "within" in some detail. The digestive process begins at the moment of the "globe," which cannot sustain the cosmic stability that it evokes. Even beyond the "distraction" that Hamlet diagnoses, the

\footnotetext{
${ }^{23} 106$ in Epitaphes; 241 in the cited facsimile edition.
} 
problems multiply. The "globe," like the "machine," is furnished forth into a new scenario that no longer suits: its privileged, geocentric topology references an "outmoded" belief (2.2.11417n). This moment also introduces the unpredictable leftoverness of writing, not only in the "book and volume of [Hamlet's] brain" but also in the scribbled commonplaces he commits—or wants to commit-to his "tables" (1.5.107). The stately, concentric overwrittenness of the "globe"-linked to speech and hearing—is, perhaps as a consequence, infiltrated and disrupted by the clowning overwrittenness that seems linked to writing. For example, Hamlet probably shouldn't have figured himself as the paradigmatically immobile "globe" only moments after he was so forcefully interpellated as a "son"/“sun," who, in a geocentric cosmos, will doubtlessly move. It was also probably impolitic to give "memory"-another means of furnishing language forth - a "seat" in the Globe, a gesture that risks riling the standing room groundlings who, though allegedly "capable of nothing but inexplicable dumb-shows and noise" (3.2.11-12), later prove capable of very nearly converting their noise into revolution on Laertes' behalf (4.5.96111). And the staging doesn't help: at the moment that Hamlet enunciates the "globe," it seems unlikely that he is performing the stability of the globe: he is ranting, calling (maybe looking?) for his tables (demanding them from the audience?), or perhaps trying to write in them. He is reeling about the stage, emitting what Horatio will call "wild and whirling words" (1.5.132), looking for all the world like a celestial object about to come unstuck from its long-standing pride of place.

Hamlet's reeling body-machine enacts the demise of a cosmic system and, in the same moment, the systems of political command and theatrical reception for which that cosmic system was a model. This collapsing system will find itself indigested, instead, in Hamlet's "within," his body-machine. We have already seen the "machine" enact a reconfigured overwrittenness. It also 
tracks this reconfiguration of overwrittenness from "global" extroversion to "machinic" introversion. One of its constituents - the cosmic-machine (1a) — points us to the "globe," affiliating its overwrittenness with this calamity of planets and of theatrical reception. Things intensify as another of these leftover agencies enters the scene both to reinforce planetary dislocation and to inflict itself on Hamlet's repertoire. Old Hamlet and his armor-machine, transformed into a "pioner[ing]" "old mole" $(1.5 .162,161)$, lead Hamlet and his companions on a merry chase across the stage. Following the interview with the Ghost and once again attempting to secure a promise, Hamlet persuades his companions to swear secrecy about the night's events. Having done so, Hamlet furnishes forth the demand that they swear again, this time by his sword (154-55). When they demur_ “We have sworn my lord already" (147) — the commandment of the Ghost issues up through the floor: "Swear" (155). After a second such "Swear" (160), Hamlet decides that it's time for them to "shift [their] ground" (156). He and his companions wheel across the stage as a little, scurrying planetary system in which there is no doubt that the "son"- he of the recently stable "globe"- doth move. Rather than assuming the privileged topology of the "book and volume" of Hamlet's brain, moreover, the energies of the collapsing cosmos and the burrowing old mole inflict themselves on the "baser matter" of Hamlet's body, if in no other way than through the sheer effort of running across the stage. By the time Hamlet is able to say "rest, rest, perturbed spirit" (1.5.180), he is surely in need of a rest himself_ —all the more reason for leisurely colloquies with Reynaldo and Voltemand.

Through this staging, the leftover agencies of the "machine" indicate the material processes that inflict themselves on Hamlet's body, indigesting not only his rhetorical repertoire but also his physical behaviors. The "machine" dynamically stages this infliction as its leftover definitions leap out to associate with these processes which then inflict themselves on the flesh, 
crashing back "within." Hamlet's flesh inherits the debased energies of these collapsing systems (cosmic, theatrical, political) as well as the clowning connotations of the "machine." The cataclysm of this infliction both of matter and of salleted words (and, for that matter, of his father's sallet-helmet) is pointed up by the equine valence of the siege-machine. If the paradigm of this "machine" was the Grecian "machine huge," then the equine charge might transfer to the armor-siege-machine of the father to cast the chase of the "old mole" as a furnishing forth of the story of Phaeton, the son of the sun who tangled with his father's horses-or, here, his father-ashorse.

What interaction between writing and the repertoire is modeled here? We have seen playgoer perception emancipated from the rhetorical claims of Hamlet's "globe" (and, earlier, Claudius' "affair") but then indigested by the multiplicity of overwritten agency. We have seen player behavior "given unsmoothness," instead of the "smoothness" that Hamlet recommends (3.2.8), by the materiality with which this overwrittenness affiliates itself. Might we be watching the author disabling his competitors in authorship — players, playgoers — and subordinating their repertoires, even in their indigestive unsmoothness? I do not think so. Here, the "domicilization" (Derrida, Archive 2; Derrida's emphasis) of overwrittenness in Hamlet's "within" is more anarchic than archival or authorial, more "house party" than "house arrest"; the author's control seems minimal even as the agencies of his writing indigest the repertoire. We might risk thinking about this relationship through the old story that Shakespeare himself played the Ghost ${ }^{24}$ : then the planetary cavort across the stage allegorizes not only Hamlet's unmanageable inheritance but the agency of the author in dramatic performance. Shakespeare here hardly determines Burbage's performance. Perhaps he determines Burbage's direction, but this is uncertain. We

\footnotetext{
${ }^{24}$ Nicholas Rowe claimed to have heard nothing else about Shakespeare's acting career "than that the top of his Performance was the Ghost in his own Hamlet" (Rowe).
} 
cannot be sure whether Hamlet moves toward or away from the sound. One imagines Burbage interacting virtuosically (or ineptly; no need for hero worship!) with the inciting energy of Shakespeare's "Swear!" The author, trapped under the stage, would have no way of knowing or directing what Burbage was doing, and the actor might not know where the burrowing author was going next.

But what of the Trojan dimension of this interaction? If Hamlet is, indeed, crammed with writing, shouldn't this writing, according to antiquity's leftover story, at some point burst forth to the danger of Denmark, the player, and the playgoer? Shouldn't this ingested writing, according to the story, conquer and enslave the lookers on? That is how the story goes, but not how things play out. Rather than vomiting up a commandment to seize on the repertoire, the fate of this Trojan Machine is to function as the first generation in an equine dynasty tracing a developing relationship between indigested writing and the repertoire. After Burbage/Hamlet's encounter with the Trojan/Phaeton-machine, Hamlet, before The Mousetrap, laments the "hobby-horse" who "is forgot" (3.2.128). Finally, as Claudius is scheming with Laertes, he recalls "Lamord," the Norman horseman (4.7.80-100). If the Trojan Machine packs dangerous, overwritten potentiality, these other figures present different images and qualities of horsemanship: Phaeton presents it as a cosmic catastrophe; the "hobby-horse," consisting of the "figure of a horse fastened round the waist of a man" (Jenkins 500) "worn by a morris dancer" (3.2.127n), manifests folksy amateurism; Lamord presents an incomparable, indescribable virtuosity.

Instead of imagining the violent reflux of indigested dramatic agency, this equine inheritance appears to map a gradual accommodation of the repertoire to indigestion from the Phaeton calamity to the virtuosic Lamord. And yet, we cannot be certain of this accommodation. We are never granted complete, perceptual access to this accommodation, a point highlighted by 
the fact that each figure of horsemanship is somehow secret. The Phaeton-father is hidden under the stage, is only retrospectively named by the "machine," and is the "wondrous strange" thing undreamt by Horatio's “philosophy” $(1.5 .163,166)$. The Trojan Machine is a paradigm of secrecy and our one encounter with it in the play is missed: when we join the action of Pyrrhus' revenge, already in progress, he has exited "th' ominous horse" (2.2.392). The "hobby-horse" is "forgot" and, as Jenkins writes, was the "type of what is forgotten" (3.2.132-33n); and Lamord "[s]o far ... topped [Claudius"] thought" that the King "in forgery of shapes and tricks / Came short of what he did" $(4.7 .87,88-89) .{ }^{25}$

This thought-topping secrecy evokes claims that, in the "coercively timebound sequence of performance" (Berger), we might "come short" (Claudius) of the "unattainable" (Lamb) relationship between word and action, between (literary) overwrittenness and the necessary questions of a moment or of a play. There can be no certainty whether we are like Lamord or Phaeton, the Trojans or simply the hobby-horse in our efforts to bring overwrittenness in relation to performance. We might think that our "prophetic soul[s]" are virtuosically seizing significance "as swift / As meditation or the thoughts of love" (1.5.40, 29-30), but we might just be performing a mockery morris dance of comprehension and interpretation amidst the sheer bandwidth of dramatic performance. From this, however, we need not deduce the superiority of the "decelerated" reader. Instead, we ought to admit that although we may not be able to catch every overwritten agency before it achieves escape velocity past our emancipated ears — we may not even try! we might make a hash of it!-we will have the opportunity to seize on the "literariness" of the play before it gallops into the study. We will also have the opportunity to

\footnotetext{
25 The well digested, calculable horses of The Mousetrap have drawn "Phoebus' cart" "full thirty times" around a geocentric sky (3.2.148) and hark back to the extroverted orderliness of the "globe" and its attendant cosmic and theatrical models.
} 
talk about these efforts (with our friends! at a party!). The uncertain, potentially infinite process of trying to calibrate a suitable relationship between word and action is what produces, in the play's final scene and in its aftermath, the staging of a dramatic democracy, as writing indigests all the repertoires on - and, indeed, off - the scene.

\section{Anti[c]ke Roman(s)}

Claudius, through his appeal to "better wisdoms," and Hamlet, through the "globe," both aspire to well digest the behaviors of their political and theatrical audiences. By the time of the "machine" and the Blurb, the fantasy of rhetorical authority that sustained these aspirations has been undone - indigested - by the duplicity of overwrittenness. The democratic space opened by this indigestion is staged, for example, in the critical response to the outmoded aurality of the supposedly "excellent play"- “This is too long," Polonius complains (2.2.436), and Hamlet, perhaps impatiently, urges the Player to "come to Hecuba" (439)_ and finds its climax in Horatio, who brings the play to its "anti[c]ke," democratizing conclusion. ${ }^{26}$

Horatio is supposed to give the play its final digestion, rescuing Hamlet's "wounded name” (5.2.328) and pacifying “men's minds" lest the opening moments of Fortinbras' regime be afflicted with "mischance / On plots and errors" (378, 378-79). He should do so with the confidence of the "globe" and by translating the play into a founding epic-narration. His capacity to so translate theatre is called into question as overwrittenness indigests his tongue. Horatio seeks to refuse his task of foundation by drinking the last dregs of the poisoned cup, declaring, "I am more an antique Roman than a Dane" (325). This attempt to plug into the theatre's tragic machinery and to avoid "report[ing] [Hamlet] and [his] cause aright / To the unsatisfied"

\footnotetext{
${ }^{26}$ Horatio has recently been claimed as a democratic hero by a range of critics (Deutermann; Lupton; Warley; Wong). In a dramaturgical sense, it is his incapacity, as much as his capacity, that makes him one.
} 
(5.2.323-24) is undercut by the affiliation of "antique" Romannness precisely with narration and foundation. Although Horatio means to invoke the Romannness of heroic suicide, his repertoire of self-slaughter is disabled by the connection between antique Romanness and epic-narration, a connection Hamlet manifests in the most antique Roman of them all: Aeneas, whose epic "talk to Dido" (2.2.384) is the speech that Hamlet—unlike, as we have seen, Polonius_- "chiefly loved" (383) in the "excellent play." Horatio stumblingly invokes that which he means to avoid.

If Horatio's repertoire of suicide is diverted into one of regime foundation by the duplicity of "antique" Romanness, his repertoires of suicide and of foundation are mocked in turn. Aeneas must share lingual real estate with another theatrical figure: the clown. In all modern editions, Horatio claims to be an "antique Roman," splitting himself between tragic suicide and epic foundation. In the earliest texts — and until the Fifth Quarto, printed in 1637— he was an "anti[c]ke Roman." ${ }^{27}$ Horatio might be preparing to kill himself, he might be preparing to tell an epic tale, but he also might be preparing to play the fool (and, quite possibly, to play the fool at killing himself or telling his tale). This generic splicing recalls and reenacts the indecorous recombination of populist clown and elitist "within" staged in the Blurb. It also activates the logic of inheritance and "furnishing forth" we observed above, and not only because Horatio is to crown Fortinbras. In the play, both Aeneas and the clown are marked as passé figures ripe for reform. Neither Polonius nor Hamlet, as mentioned above, would mind a shorter version of Aeneas' speech; the clown, of course, is a major topic of Hamlet's reforming Advice. By indigestively speaking more than is set down for him, Horatio furnishes forth these two traditions, reanimating them and, finding himself at their confluence, inscrutably projecting them

\footnotetext{
${ }^{27}$ In Q2, the word is printed "anticke"; in the Folio and Q1 as "Antike." "Antique" and "anti[c]ke" were both available as spellings but were used for either meaning. I retain the bracketed "[c]" to highlight the implication of this enunciation with writing and with print.
} 
forward into his narration and the new regime. We may be disturbed that Horatio is experiencing this indecision at the moment he is supposed to found a regime. On the other hand, we might find pleasure in this hesitation and its "mingling [of] kings and clowns" (Sidney). Casting himself as an "anti[c]ke Roman" certainly situates Horatio as the miscegenated inheritor of king (who delighted the judicious) and clown (who delighted the groundlings); it also makes him the joiner of a pair of "anti[c]ke" Romans who stood as indexes of theatrical quality: for the Players, it was said that "Seneca cannot be too heavy nor Plautus too light" (2.2.336-37). We might also delight at detecting in Horatio's ensuing performance a "variety of ingredients" commensurate with his tongue's inscrutable, "thought-topping" mingling of the "antique" and the "antic" Roman (or, then again, we might argue that Horatio pulls it together and does well by his name; no need to subordinate his repertoire alone!).

Horatio's "anti[c]ke" enunciation situates him as the inheritor of the best the theatre has had to offer and, in doing so, casts him as a new model of theatrical pleasure, one in which we can't be certain which parent's traits are dominant and in which this indecision is precisely the point. He also convenes a kind of long dramaturgical parliament running not only from Plautus to Will Kempe but also from the author to the scribe to the actor to the playgoer to the editor to the printer to the reader in which none of the participants have the repertorial competence to say exactly what work, in that moment, was supposed to be going on. Neither the most virtuosic actor's voice nor the most acute audience's ear can piece out the genre of Horatio's intentions. But the blame falls too on author's pen, printer's press, and reader's eye. No one in the many stomachs of dramatic production has managed to well digest this "anti[c]ke" sallet, nor could they. Instead, it goes a progress through the guts of the study, the theatre, and the printing house, 
disabling repertoires on its way and, in the same gesture, bringing them all into play. ${ }^{28}$ This indigestive progress is anticipated in the Blurb where the task of "set[ting] down" a "well digested scene" seems like the author's, but this task is figured as cookery—seasoning and not over-seasoning lines - for the actor who will "mouth" it (3.2.2) even though it is the spectator who receives "a taste of . . quality" (2.2.369). Horatio's anti[c]ke, indigested tongue radicalizes this dramaturgical democracy, inviting everyone to a feast they can't hope to finish.

We live in a disciplinary moment characterized by, as Joseph Roach writes, a "widening gap between performance studies and literary studies" ("Blunders" 1080) and, in Shakespeare studies, what Weimann calls an "alienation between textual and performance approaches" ("Performance" 4). ${ }^{29}$ These gaps and alienations have been notably conditioned by the twin gestures of emancipation — of performance from text, of literature from performance - that we identified above. Hamlet, by contrast, stages the indigestion of "literary" overwrittenness into the scene of performance, an indigestion that, at least until 1637, culminates on Horatio's "anti[c]ke" tongue. In Hamlet, this indigestive progress redesigns drama's participation in performance, from the authoritarian rhetorical fantasies of the first act to the collective pleasures of the last. Its dramaturgy refuses the coercions that allegedly arise at the intersection of writing and performance and, instead, highlights and even celebrates the parties, protests, and debates that flourish there.

\section{WORKS CITED}

\footnotetext{
${ }^{28}$ An extended indigestion emblematized by the sallet-helmet which would, after all, not only be difficult to digest but could also lead to all sorts of gastric problems if filled with wine and/or poison.

${ }^{29}$ On these and other disciplinary alienations, including between theatre/performance studies and the digital humanities, see also Worthen, Shakespeare Performance Studies.
} 
Aristotle. Poetics. Trans. S. H. Butcher. Internet Classics Archive. MIT. 1994-2009. Web. 9

Sept. 2015.

Bailes, Sara J. Performance Theatre and the Poetics of Failure: Forced Entertainment, Goat Island, Elevator Repair Service. New York: Routledge, 2011. Print.

Beckerman, Bernard. Theatrical Presentation: Performer, Audience, and Act. Eds. Gloria Brim Beckerman and William Coco. New York: Routledge, 1990. Print.

Bennett, Benjamin. All Theater Is Revolutionary Theater. Ithaca: Cornell UP, 2005. Print.

Berger, Harry, Jr.. Imaginary Audition: Shakespeare on Stage and Page. Berkeley: U of California P, 1990. Print.

-. Situated Utterances: Texts, Bodies, and Cultural Representations. New York: Fordham UP, 2005. Print.

—. "Text against Performance in Shakespeare: The Example of Macbeth." Genre 15.2-3 (1982), 49-79. Print.

Borlik, Todd. “'The Chameleon's Dish': Shakespeare and the Omnivore's Dilemma." Early English Studies 2 (2009), 1-29. Print.

Colonna, Francesco. Hypnerotomachia: The Strife of Love in a Dreame (1592). Trans. R. D. Delmar, NY: Scholars' Facsimiles \& Reprints, 1973. Print.

Cox, John D. Shakespeare and the Dramaturgy of Power. Princeton: Princeton UP, 1989. Print. de Grazia, Margreta. "Harry Berger Jr. and the Tree of Acknowledgment" Shakespeare Quarterly 62.4 (2011), 541-554. Print.

Derrida, Jacques. Archive Fever: A Freudian Impression. Trans. Eric Prenowitz. Chicago: The U of Chicago P, 1995. Print. 
Deutermann, Allison K. "'Caviare to the General'?: Taste, Hearing, and Genre in Hamlet." Shakespeare Quarterly 62.2 (2011): 230-55. Print.

Erne, Lukas. Shakespeare As Literary Dramatist. 2nd ed. Cambridge: Cambridge UP, 2013 [2003]. Print.

Ferguson, Margaret W. “Hamlet: Letters and Spirits.” Eds. Patricia Parker and Geoffrey Hartman. Shakespeare and the Question of Theory. London: Methuen, 1985.

Gallagher, Catherine and Stephen Greenblatt. Practicing New Historicism. Chicago: U of Chicago P, 2000. Print.

Garner, Stanton B. Bodied Spaces: Phenomenology and Performance in Contemporary Drama. Ithaca, N.Y: Cornell UP, 1994. Print.

Greenblatt, Stephen, et al. eds. The Norton Shakespeare. 3rd ed. New York: Norton, 2015. Print.

Goldman, Michael. The Actor's Freedom: Toward a Theory of Drama. New York: Viking, 1975. Print.

Harding, James M. and Cindy Rosenthal, eds. The Rise of Performance Studies: Rethinking Richard Schechner's Broad Spectrum. New York: Palgrave Macmillan, 2011. Print.

Harris, Jonathan Gil. “Surviving Hamlet.” Shakespeare Quarterly 62.2 (Summer 2011), 145-147. Print.

Hillman, David. Shakespeare's Entrails: Belief, Skepticism and the Interior of the Body. New York: Palgrave Macmillan, 2007. Print.

Lamb, Charles. "On the Tragedies of Shakespeare Considered with Reference to their Fitness for Stage Representation” Bartleby. 1993-2015. Web. 11 Sept. 2015.

Lehmann, Hans-Thies. Postdramatic Theatre. Trans. Karen Jürs-Munby. London: Routledge, 2006 [1999]. Print. 
Lesser, Zachary, and Peter Stallybrass. "The First Literary Hamlet and the Commonplacing of Professional Plays." Shakespeare Quarterly 59.4 (2008): 371-420. Print.

Lupton, Julia Reinhard. "Hamlet, Prince: Tragedy, Citizenship, and Political Theology.” Ed. Diana E. Henderson. Alternative Shakespeares, Vol. 3. London: Routledge, 2008, 181-203. Print.

McAlindon, T. Shakespeare and Decorum. New York: Barnes \& Noble, 1973. Print.

O’Gorman, Róisín and Margaret Werry, eds. On Failure. Spec. issue of Performance Research 17.1 (2012): 1-134. Print.

Parks, Suzan-Lori. The America Play and Other Works. New York: Theatre Communications Group, 1995. Print.

Phelan, Peggy. "'Just Want To Say": Performance and Literature, Jackson and Poirier" PMLA 125.4 (2010), 942-7. Print.

Pollard, Tanya. Drugs and Theatre in Early Modern England. Oxford: Oxford UP, 2005. Print.

Preiss, Richard. Clowning and Authorship in Early Modern Theatre. Cambridge: Cambridge UP, 2014. Print.

Rebhorn, Wayne. "Outlandish Fears: Defining Decorum in Renaissance Rhetoric." Intertexts 4.1 (Spring 2000), 3+. Literature Resource Center. Web. 28 Mar. 2016.

Richards, Jennifer. "Social Decorum in The Winter's Tale." Eds. Jennifer Richards and James Knowles. Shakespeare's Late Plays: New Readings. Edinburgh: Edinburgh UP, 1999. Print.

Ridout, Nick. Stage Fright, Animals, and Other Theatrical Problems. Cambridge: Cambridge UP, 2006. Print.

Roach, Joseph. "Performance: The Blunders of Orpheus." PMLA 125.4 (2010), 1078-86. Print. 
—. The Player's Passion: Studies in the Science of Acting. Newark: U of Delaware P, 1985. Print.

Rowe, Nicholas, Some Account of the Life of William Shakespeare (1709). Project Gutenberg. N.d. Web. 23 March 2014.

Sack, Daniel. After Live: Possibility, Potentiality, and the Future of Performance. Ann Arbor: U of Michigan P, 2015. Print.

Sale, Carolyn. "Eating Air, Feeling Smells: Hamlet's Theory of Performance" Renaissance Drama 35 (2006), 145-68. Print.

Schechner, Richard. “A New Paradigm for Theatre in the Academy.” TDR 36.4 (1992), 7-10. Print.

Schneider, Rebecca. Performing Remains: Art and War in Times of Theatrical Reenactment. New York: Routledge, 2011. Print.

Shakespeare, William. Hamlet. Ed. Harold Jenkins. London: Methuen, 1982. Print.

Shakespeare, William. Hamlet. Ed. Ann Thompson and Neil Taylor. London: Arden Shakespeare, 2006. Print.

Sidney, Phillip. A Defence of Poesie and Poems. Project Gutenberg. 8 Oct. 2014. Web. 12 Sept. 2015.

Taylor, Diana. The Archive and The Repertoire: Cross-Cultural Performance in the Americas. Durham: Duke UP, 2003. Print.

Tottel, Richard. Tottel's Miscellany (1557-1587). Ed. Hyder Edward Rollins. Cambridge, MA: Harvard UP, 1966. Print.

Turberville, George. Epitaphes, Epigrams, Songs, and Sonets (1567) and Epitaphes and Sonnettes (1576). Delmar, N.Y: Scholars' Facsimiles \& Reprints, 1977. Print. 
Trudell, Scott A. “The Mediation of Poesie: Ophelia’s Orphic Song” Shakespeare Quarterly. 63.1 (2012), 46-76. Print.

van Es, Bart. Shakespeare In Company. Oxford: Oxford UP, 2013. Print.

Warley, Christopher. "Specters of Horatio.” ELH 75 (2008), 1023-50. Print.

Weber, Samuel. Theatricality as Medium. New York: Fordham UP, 2004.

Weimann, Robert. Author's Pen and Actor's Voice: Playing and Writing in Shakespeare's Theatre. Eds. Helen Higbee and William N. West. Cambridge: Cambridge UP, 2000. Print.

—. "Mimesis in Hamlet" Eds. Patricia Parker and Geoffrey Hartman. Shakespeare and the Question of Theory. London: Methuen, 1985.

—. "Performance in Shakespeare's Theatre: Ministerial and/or Magisterial?" Eds. Graham Bradshaw, Tom Bishop, and David Schalkwyk. The Shakespearean International Yearbook 10 (2010), 3-29.

Weimann, Robert and Douglas Bruster. Shakespeare and the Power of Performance: Stage and Page in the Elizabethan Theatre. Cambridge: Cambridge UP, 2008. Print.

Wong, Timothy. "Steward of the Dying Voice: The Intrusion of Horatio into Sovereignty and Representation” Telos 153 (2010), 1-19. Print.

Worthen, W. B. Drama: Between Poetry and Performance. Chichester, UK: Wiley-Blackwell, 2010. Print.

-. Shakespeare and the Authority of Performance. Cambridge: Cambridge UP, 1997. Print.

—. Shakespeare Performance Studies. Cambridge: Cambridge UP, 2014. Print. 